\title{
Dynamics of an Insularized and Compressed Impala Population: Rainfall, Temperature and Density Influences
}

\author{
Joseph O. Ogutu ${ }^{*}, 1,2$, Hans-Peter Piepho ${ }^{1}$ and Erustus Kanga ${ }^{3}$ \\ ${ }^{1}$ University of Hohenheim, Institute of Crop Science, Fruwirthstrasse 23, 70599 Stuttgart, Germany \\ ${ }_{2}^{2}$ International Livestock Research Institute, P. O. Box 30709, Nairobi, 00100, Kenya \\ ${ }^{3}$ Kenya Wildlife Service, Ecosystems and Landscapes Conservation Department, P. O. Box 40241, Nairobi, Kenya
}

\begin{abstract}
Understanding the relative contributions of different life history stages to changes in population abundance is basic to understanding population dynamics and effective management and conservation of large herbivores. We examined temporal variation in natality, recruitment and mortality rates and sex ratio in a compressed and insularized impala population monitored daily for 211 months (17.6 years), spanning June 1994-December 2011. We related the rates to contemporaneous variation in immediate and cumulative past rainfall, temperature and prior abundance. Over the course of this 17.6-year period, the population size fluctuated between 22 and 52 individuals. A total of 213 births, mortality of 96 lambs, 33 males and 58 females; recruitment of 55 juveniles into the female category and 40 juveniles into the male category were recorded. Natural mortality averaged $2.3 \%$ of the population annually with lambs contributing $52.3 \%$, males $26.6 \%$ and females $21.2 \%$. Lamb mortality was highest in dry months, implicating food scarcity, but female mortality peaked in the wettest months and in hot, wet seasons, suggesting increased susceptibility to diseases and pathogens in hot, damp weather conditions. Male, female and overall population mortality rates were positively correlated with prior abundance, implicating negative density feedbacks on population growth. Births were aseasonal and were surprisingly negatively correlated with rainfall around the time of conception and during wet phases of a regional 5-year rainfall cycle. This implies, quite surprisingly, that high rainfall depressed reproductive success in impalas. Juvenile recruitment increased with increasing 5-month running mean of monthly rainfall but declined $(i)$ at excessively high values of annual rainfall, (ii) with increasing prior density and (iii) in hot, dry seasons. This implicates heightened competition for limiting resources and nutritional stress at high density, increased vulnerability to diseases and pathogens at high rainfall and adverse consequences of habitat desiccation and reduced activity levels at high ambient temperatures.
\end{abstract}

Keywords: Impala, births, recruitment, mortality, density dependence, rainfall, habitat compression, insularization.

\section{INTRODUCTION}

Understanding population dynamics requires accurate knowledge of the relative contributions of different life history stages to changes in population abundance (OwenSmith \& Mason 2005). Population dynamics are determined by demographic processes, in particular natality, recruitment and survival, besides immigration and emigration. These processes are often influenced by density. In ungulates, juvenile survival is the demographic parameter most sensitive to changes in prior density. It is often more variable and exerts less influence on population dynamics than adult survival among larger herbivores (Gaillard et al. 1998, 2000). In adults, survival is often higher among females than males, leading to sex ratios biased towards females (OwenSmith 1993, Toigo \& Gaillard 2003). Establishing the roles of particular demographic processes on population dynamics therefore requires accurate estimation of natality, recruitment and survival rates and their relative variation and timing. This is often difficult, however, due to large sampling errors and coarse temporal resolutions of most sampling surveys.

*Address correspondence to this author at the University of Hohenheim, Institute for crop science, Fruwirthstrasse 23, 70599 Stuttgart, Germany; Tel: +49-711-459 23022; Fax: +49-711-459-24345;

E-mail: jogutu2007@gmail.com
As a result, attribution of variation in natality, recruitment and survival rates to particular causal mechanisms often suffers from considerable uncertainty in survey data, especially for large wild populations.

Although density often exerts greater influence on juvenile than adult survival, this influence can be hard to determine because responses of demographic rates to density are most often nonlinear and become stronger at high than at low density (Bonenfant et al. 2009). Moreover, density effects are often interactive with those of the weather and become stronger in years of harsh weather (Bonenfant et al. 2009). Among most tropical ungulates rainfall is the main climatic factor controlling individual body mass and condition (Bourgarel et al. 2002, Gaidet \& Gaillard 2008), the aggregate biomass (Coe et al. 1976, Fritz \& Duncan 1994, Fritz \& Duncan 2002) and species-specific biomass (East 1984) and population abundance (Ogutu \& OwenSmith 2005, Ogutu et al. 2008) levels, as well as driving recruitment dynamics (Ogutu et al. 2011), phenology and synchrony of breeding (Sinclair et al. 2000, Moe et al. 2007; Ogutu et al. 2010) and population dynamics (Owen-Smith 1990, Mduma et al. 1999, Georgiadis et al. 2003, Ogutu \& Owen-Smith 2003, Owen-Smith \& Ogutu 2003, Dunham et al. 2004). This follows from the fact that in African savannas, rainfall largely determines the dynamics of plant 
biomass production (Sinclair 1975, Deshmukh 1984, McNaughton 1985, Boutton et al. 1988a), phenology (Prins 1988) and quality (Boutton et al. 1988b, Prins \& Beekman 1989, Georgiadis \& McNaughton 1990). Hence, the population performance of African ungulates declines during droughts because of reduced vegetation production and quality (Mduma et al. 1999, Metzger et al. 2010). Predation further limits populations of tropical ungulates (Owen-Smith $\&$ Mills, 2008), especially those of non-migratory and smallsized species (Sinclair et al. 2003, Hopcraft et al. 2010). As a result, the effects of rainfall and predation on population dynamics need to be accounted for first before those of density can be reliably revealed. Compounding the effects of rainfall, density feedback and predation are the effects of pathogens and diseases, habitat deterioration linked to rising temperatures, compression and insularization of populations by land use changes pressing against protected area boundaries.

We analyzed temporal variation in the demographic rates associated with the population dynamics of a small and completely fenced impala (Aepyceros melampus) population. Our data presents a rare opportunity to understand the influences of population compression and insularization, density feedback, rainfall and temperature fluctuations on the dynamics of abundance, lambing, recruitment, mortality and sex ratio on the impala population that was monitored daily for 17.6 years and for which the contributions of emigration, immigration, births, recruitment and mortality events to population changes were known exactly. Also, the timing of births, recruitment and mortality were known with certainty as were most causes of mortality. We tested the following hypotheses. (1) Birth and recruitment rates should reduce but mortality rates should increase with increasing density since increasing density reduces per capita resource availability. (2) Birth and recruitment rates should increase with increasing seasonal and cumulative past rainfall but mortality rate should show the opposite pattern since rainfall fundamentally controls vegetation production in African savannas. (3) High temperatures should elevate impala mortality because high temperatures cause vegetation desiccation, reducing the capacity of plants to retain green (nutritious) leaves through the dry season and promote activities of parasites and pathogens in the wet season. (4) The small size and complete fencing of the Impala Sanctuary and paucity of large predators should exacerbate the adverse effects of high density and temperature and very low or excessive rainfall on birth, recruitment and survival rates of impala, leading to intermittent population crashes whenever the number of impalas exceeds the carrying capacity of the Sanctuary.

\section{METHODS}

\section{Study Area}

The Kisumu Impala Sanctuary is located $3 \mathrm{~km}$ southwest of the center of Kisumu City in Kenya $\left(0^{\circ} 6^{\prime} 0^{\prime \prime} \mathrm{S}, 34^{\circ} 45^{\prime} 0^{\prime \prime}\right.$ E, $1200 \mathrm{~m}$, a.s.1). The Sanctuary consists of two separate sections located about $500 \mathrm{~m}$ a part and covering a total area of 48.6 ha. The northern section covers some 20.2 ha, is partly fenced by a chain link and concrete wall on the east, and bounded on the west by $c a .2 \mathrm{~km}$ strip of the bank of Lake Victoria and on the east and north by Kisumu City. The lake shore consists of low-lying beaches, covered with scattered swamps. The beaches rise to a height of nearly 10 $\mathrm{m}$ over a distance of $200 \mathrm{~m}$ from the lake. The swamps on the beachfronts in part of the northern section are slashed monthly in the dry season but weekly in the wet season to enable access by people and impalas. The beachfronts, shores and ridges are covered by recent sedimentary deposits, rocky terrain and phonolitic (derived from a dark colored rock containing feldspathoid minerals) and acidic soils overlain with sands and fine clay.

The Sanctuary is covered by 126 plant species dominated by woodlands and grasslands and supports trees and shrubs, the vast majority of which are indigenous to the area. The woodland vegetation is green throughout the year. The southern section is covered with dense papyrus, making it unsuitable for most ungulate species. The free-ranging large animals using the Sanctuary include impalas, hippos (Hippopotamus amphibius), crocodiles (Crocodilus niloticus), the savanna monitor lizard (Veranus spp) and the python (Python sebae). A small, section of the Sanctuary serves as an orphanage and holding point for captured problem animals held in cages.

The Sanctuary receives rainfall in two seasons. The long rains start in March and end in May and the short rains span October to December. Due to heavy rainfall and poorly drained soils about $60 \%$ of the northern section and the whole of the southern section of the Sanctuary becomes waterlogged in the wet season. Temperatures are warm yearround.

\section{The Study Population}

The impala has a gestation period of 6.5-7 months and wean their young after 4 months. Females reach sexual maturity and conceive at two years of age and give birth to a single young (Fairall 1983). The impala is a selective feeder that primarily depends on browse in the dry season but on grass in the wet season, reflecting the seasonal variation in the nutritional quality of these two plant groups (Fairall 1983, Klein \& Fiarall 1986). Selectively feeding on forage rich in crude protein makes impala dependent on permanent drinking water to satisfy their relatively high water turnover rates linked to excreting nitrogenous waste in urine (Fairall \& Klein 1984). Impala therefore drink water daily when available (Gaidet \& Gaillard 2008).

We focus here on the impala population located in the northern section of the Sanctuary. These impalas are free ranging and feed on natural vegetation. The Kisumu Impala Sanctuary was established and fenced in 1974 when it had 57 impalas and gazetted as a national conservation area in October 1992. The Sanctuary fence was renovated or reinforced in 1980 and in 1986 when the Sanctuary had 27 impalas. A concrete wall was erected along the eastern perimeter of the Sanctuary in 2007. A herd of 12 impalas were translocated to the Sanctuary from a remnant population in the environs of Kisumu City on 2 August 1990. This formed part of efforts to save the Kisumu impala population whose former range was progressively being taken up by the expansion of Kisumu City since its inception in 1900. The few other remaining impalas $(n=14)$ in Kisumu City were translocated during 13-21 July 1976 to the Ndere Island $\left(4.2 \mathrm{~km}^{2}\right)$, located inside Lake Victoria, some $25-30$ 
$\mathrm{km}$ south west of Kisumu City and gazetted as a National Park on 31 July 1987. Except for two killed on 31 January 1996 for veterinary examination, the impalas are not culled. However, in December 2007, 10 males were translocated from the Sanctuary and 11 foreign males introduced into the Sanctuary from Lake Nakuru National Park to reduce inbreeding. Thereafter no more impalas were brought into or taken away from the Sanctuary till December 2011. Since impalas cannot move out of the Sanctuary and since they are not culled except for rare veterinary examinations, any change in their number is due solely to births, deaths or translocations.

\section{Daily Census of Impalas}

The impala population is counted daily by Kenya Wildlife Service (KWS) rangers since 1 June 1994. When individuals, usually bachelor males or sick animals, which break away from the main herds, are missed during the daily counts their numbers and details (sex and age class) are noted daily until they are either resighted or their carcasses are found. The time series of counts reported here covers 1 June 1994 to 30 December 2011. The number of all impalas, the birth of lambs and mortality of individuals of all ages and the causes of mortality, where known, are recorded daily. The impalas are grouped into newborn lambs $(<1$-month old), juvenile ( $<6$-month old) and older ( $>6$-month old) age classes. The older individuals are sexed. Animals that look sick, weak or are injured are noted and closely monitored and reported to KWS veterinarians. The number of animals in each age and sex class recorded on the last day of each month is taken to represent the number of live animals in the month. This number is updated in the following month by adding the number of births and subtracting the number of deaths. Counts were not conducted only during JanuaryMarch 1999 and June-August 2008. For April 1999, records were available from the $20^{\text {th }}$ day onward.

\section{Rainfall and Temperature}

Average monthly rainfall, minimum and maximum temperatures records for 1957-2011 were obtained from the nearby Kisumu Airport Meteorological Station to provide broad temporal contexts for evaluating the rainfall and temperature patterns observed during our study period (1994-2011).

\section{Statistical Data Analyses}

The statistical analyses aimed to reveal how abundance, births, recruitment, mortality and sex ratio and the seasonal timing of births were influenced by prior density, rainfall and temperature fluctuations during 1994-2011. We classified years with rainfall (seasonal and annual components) within the $0-10,11-25,26-40,41-75,76-90,91-95$ and $96-100^{\text {th }}$ percentiles of their respective frequency distributions during 1957-2011 as extreme, severe or moderate drought years (seasons), or as average, wet, very wet or extremely wet years (seasons, Ogutu et al. 2007) to characterize years in terms of rainfall deficit or surfeit and represent broad transitions in vegetation conditions (Scholes \& Archer 1997, Sankaran et al. 2005).

We calculated (1) overall abundance, sex and agespecific abundances for the older impalas, (2) sex ratio
(Females /100 Males), (3) apparent birth rate (lambs /100 females), (4) apparent juvenile recruitment rate (juveniles /100 females), (5) apparent female recruitment rate (female recruits /100 females), (6) apparent male recruitment rate (male recruits $/ 100$ males), (7) lamb mortality rate (all dead lambs /100 impalas), (8) female mortality rate (all dead females /100 impalas), (9) male mortality rate (all dead males / 100 impalas) and (10) total mortality rate (all dead impalas /100 impalas). We also calculated the proportional contributions of lamb, male and female mortality to the total mortality rate. Each of these rates was averaged across all months within each year to derive annual rates. We used these rates to examine variations in birth, recruitment and mortality across years in relation to prior rainfall and density and seasonal and annual minimum and maximum ambient temperatures after controlling for rainfall because temperature can be correlated with rainfall. To derive the monthly distributions of birth and lamb mortality rates we averaged the rates for each month across all years.

The following statistics were derived from rainfall and used in the statistical analyses. Moving averages of monthly rainfall were computed over periods spanning 4-9 months before the birth month, selected to encompass the months of conception 6-7 months before birth estimated by backdating recorded birth months by the gestation length of 6.5-7 months for impala. We also computed running means of monthly rainfall over 0 to 6 months from the month of the count as well as running means of the dry and wet season and annual rainfall over 1 to 5-year windows to represent wet and dry phases of the regional 5-year rainfall oscillation.

\section{Rainfall and Density Influences}

We regressed monthly birth rate against mean monthly rainfall averaged over 4-9 months prior to the birth month to establish how habitat conditions around the time of concepttion influenced conception rate and hence birth rate. We also regressed the monthly mortality rates, recruitment rate and sex ratio against the 1 to 6 -month running means of monthly rainfall averaged over all the years to assess how these rates were influenced by variation in immediate rainfall. We further regressed birth, recruitment and mortality rates and sex ratio against the 1 to 5-year running means of the wet and dry season and annual rainfall to establish how the phases of the 5-year oscillation in the seasonal and annual rainfall components affected these demographic rates. We used standard normal-theory regression models fitted by the restricted maximum likelihood method and the corrected Akaike Information Criterion (Burnham \& Anderson 2002, Appendix Table A1) computed by the maximum likelihood method to select the best-supported monthly and cumulative past rainfall components. The monthly and cumulative past rainfall components were fitted in separate regression models. We also used the Pearson or Spearman rank correlation coefficient to explore relationships between the demographic statistics and prior rainfall and prior density as well as between the demographic rates and standardized seasonal and annual minimum and maximum components of temperature after partialling out the corresponding seasonal or annual rainfall components. Lastly, we summarized deaths by their reported causes and results of postmortem examinations conducted by KWS veterinarians. 


\section{RESULTS}

\section{Rainfall and Temperature Patterns}

Rainfall is bimodal with a major peak in April, during the long rains, spanning March-May and a minor peak in
November, during the short rains, covering NovemberDecember (Fig. 1a). During 1963-2011 the annual (OctoberSeptember), wet (October-May) and dry (June-September) season rainfall components, respectively, averaged $1368.0 \pm 212.2 \mathrm{~mm}$ (range 856.6-1860.5 mm), 1030.2 \pm 213.6

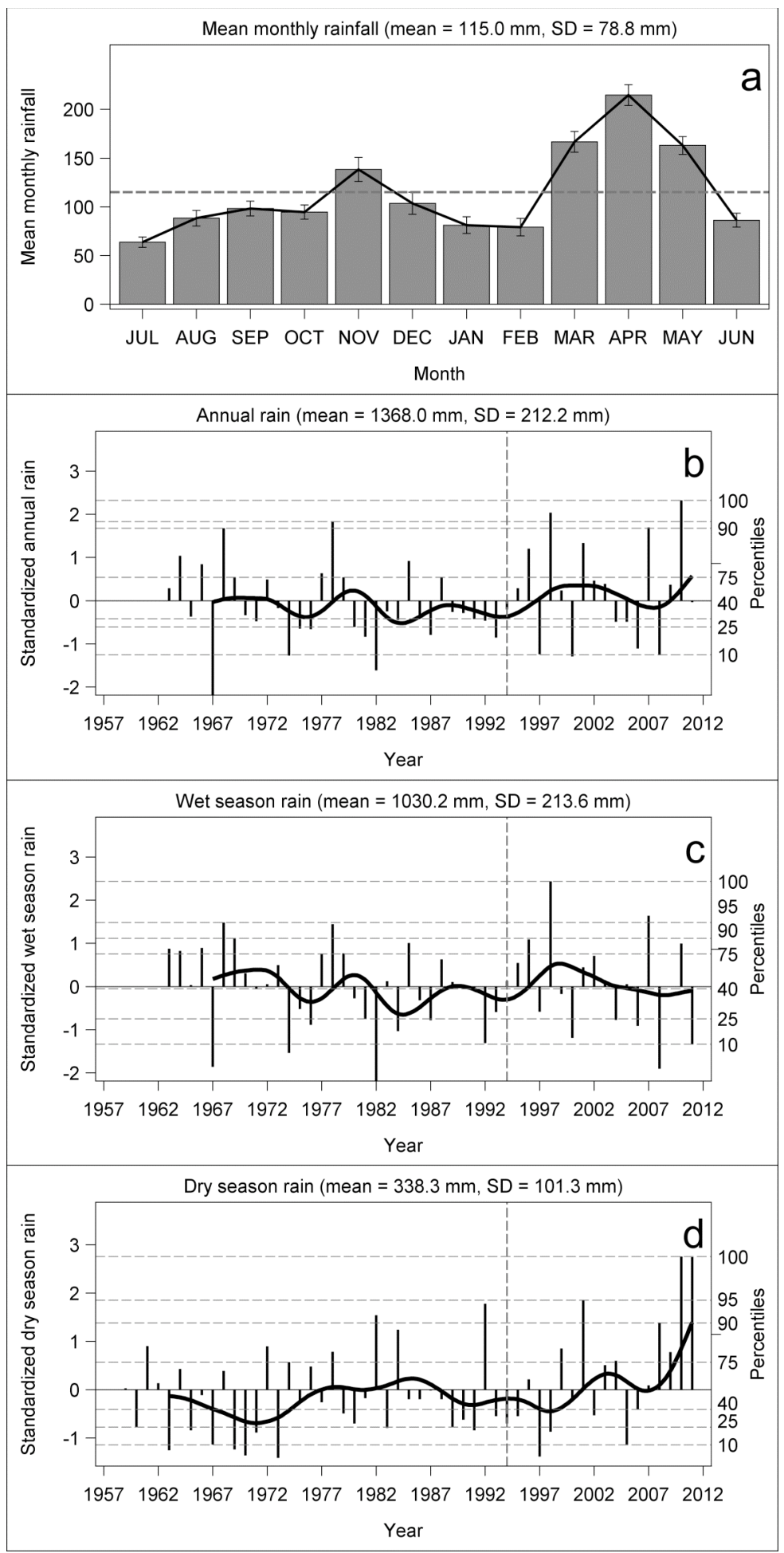

Fig. (1). The average monthly rainfall showing a bimodal pattern (a) and the interannual variation in the standardized annual (November to October, (b)), wet (November-May, (c)) and dry (June-October, (d)) season rainfall in Kisumu during 1959-2011. The vertical needles are the standardized rainfall; the solid lines are the 5-year running means for the seasonal and the annual rainfall components. The dashed horizontal lines are the $10,25,40,50,75,90,95$ and $100^{\text {th }}$ percentiles of the frequency distributions of the seasonal and annual rainfall normalized to zero mean and unit variance. The dashed vertical lines mark the start of the monitoring period in June 1994. 
$\mathrm{mm}$ (range 530.5-1550.7 $\mathrm{mm}$ ) and $338.3 \pm 101.3 \mathrm{~mm}$ (194.9$617.6 \mathrm{~mm}$ ). The wet and dry season and annual rainfall components showed approximate 5-year quasi-periodic oscillations during 1963-2011 (Figs. 1b-d), meaning that Kisumu receives high rainfall for approximately five years followed by low rainfall for a further five years. Extreme droughts were recorded in 1967, 1974, 1982, 2000 and 2008; severe droughts in 1975-1976, 1980-1981, 1987, 1993, 1997 and 2006. Extremely wet years were 1998, with extreme ENSO floods, and 2010, whereas 1978 and 2007 were very wet years (Figs. 1b-d).

Temperatures were warm all year with a mean monthly minimum of $17.1 \pm 0.96{ }^{\circ} \mathrm{C}$ (range $=14.3-23.1{ }^{\circ} \mathrm{C}, n=660$ months) and maximum of $29.5 \pm 1.61{ }^{\circ} \mathrm{C}$ (range $=20.6-$ $34.0{ }^{\circ} \mathrm{C}, n=660$ months) recorded during January 1957December 2011. During 1957-2011 the minimum tempe- rature increased by $0.84 \pm 0.381{ }^{\circ} \mathrm{C}$ from $17.2{ }^{\circ} \mathrm{C}$ in October 1957 to $18.0{ }^{\circ} \mathrm{C}$ in October 2011 . This increase was significant ( $t=2.21, D F=1302, P=0.0270)$ based on a contrast of constructed spline effects (located at October 1957 and October 2011 on the running time) using a penalized cubic Bspline basis with three equally spaced interior knots (SAS Institute 2011). The maximum temperature also increased in the same period, albeit insignificantly $(t=1.51, D F=1302, P$ $=0.1310$ ) by $0.576 \pm 0.381{ }^{\circ} \mathrm{C}$ from 29.4 to $30.0{ }^{\circ} \mathrm{C}$. The maximum temperature exceeded the 1957-2011 mean in February 1985 but the minimum temperature did so in November 1984 (Fig. 2). The minimum temperature was notably high in June $\left(22.4{ }^{\circ} \mathrm{C}\right)$, November $\left(20.3{ }^{\circ} \mathrm{C}\right)$ and December $\left(20.7^{\circ} \mathrm{C}\right) 1993$ and June $\left(22.6{ }^{\circ} \mathrm{C}\right)$ and December $\left(23.1^{\circ} \mathrm{C}\right) 2000$ (Fig. 2a) whereas maximum temperatures were unusually low in 1970 (Fig. 2b).
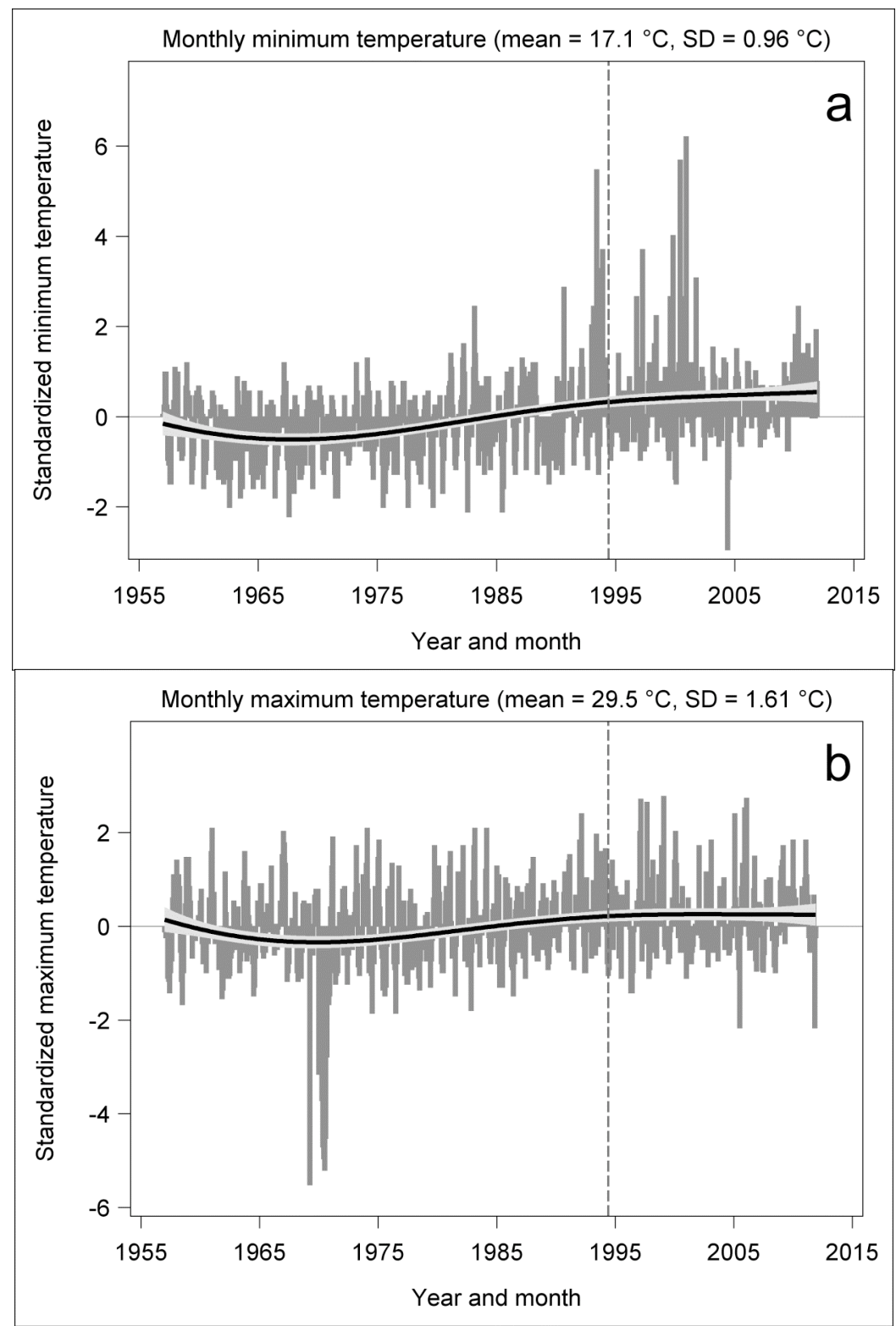

Fig. (2). The temporal fluctuations in the minimum (a) and maximum (b) temperatures in Kisumu during January 1957 to December 2011 standardized to zero mean and unit variance (needles) and the trend curve and its $95 \%$ point wise confidence band based on a penalized cubic B-spline with 20 equidistant interior knots and a third-order difference penalty on the B-spline coefficients. The dashed vertical lines mark the start of the monitoring period in June 1994. 
Temporal Trends in Abundance, Sex Ratio, Births, Recruitment and Mortality Rates

The total and age-and sex-specific population abundances fluctuated widely, largely due to monthly fluctuations in abundance of juveniles (range 0-21 animals), and high mortality (range 1-13 animals), in particular of females (Fig. 3a). Also, high juvenile recruitment during 2002-2008 ( $n=$ 33 recruits), except during the drought of 2006, led to population increase in this period (Fig. 3b). The number of newborn lambs was noticeably low in some months (e.g. zero during the ENSO floods of 1998), but high in others, and showed a quasi-cyclic pattern (Table 1, Fig. 3b).

Sex-specific disparities in recruitment and mortality were associated with marked temporal variation in sex ratios. Thus, the recruitment of 10 juvenile females and no male during the extreme drought of 2000 and the death of 12
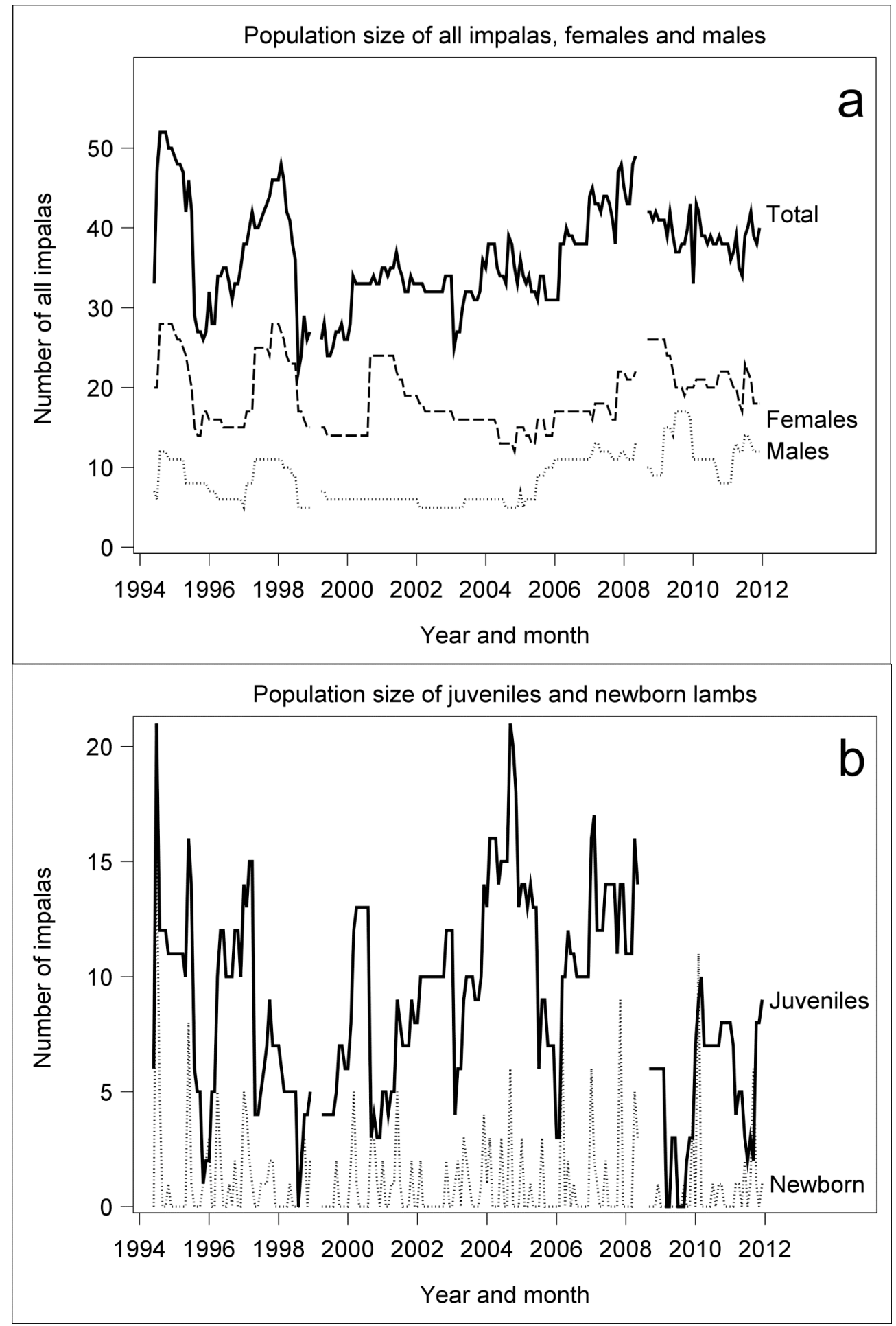

Fig. (3). Temporal trends in the number of all, female and male impalas (a) and juvenile and newborn impalas (b) in Kisumu Impala Sanctuary during June 1994-December 2011. Line breaks indicate missing counts. 
Table 1. The Monthly Average Number of Impalas Counted in each Year, Grouped by Age and Sex Class, and the Observed Number of Births, Recruits and Dead Impalas Summed Over all Months in each Year during June 1994-December 2011. Since surviving newborn lambs graduate to the juvenile class within the year, the number of juveniles in the table should be halved so that lambs do not contribute twice to total numbers in the same year (towards the newborn and juvenile categories).

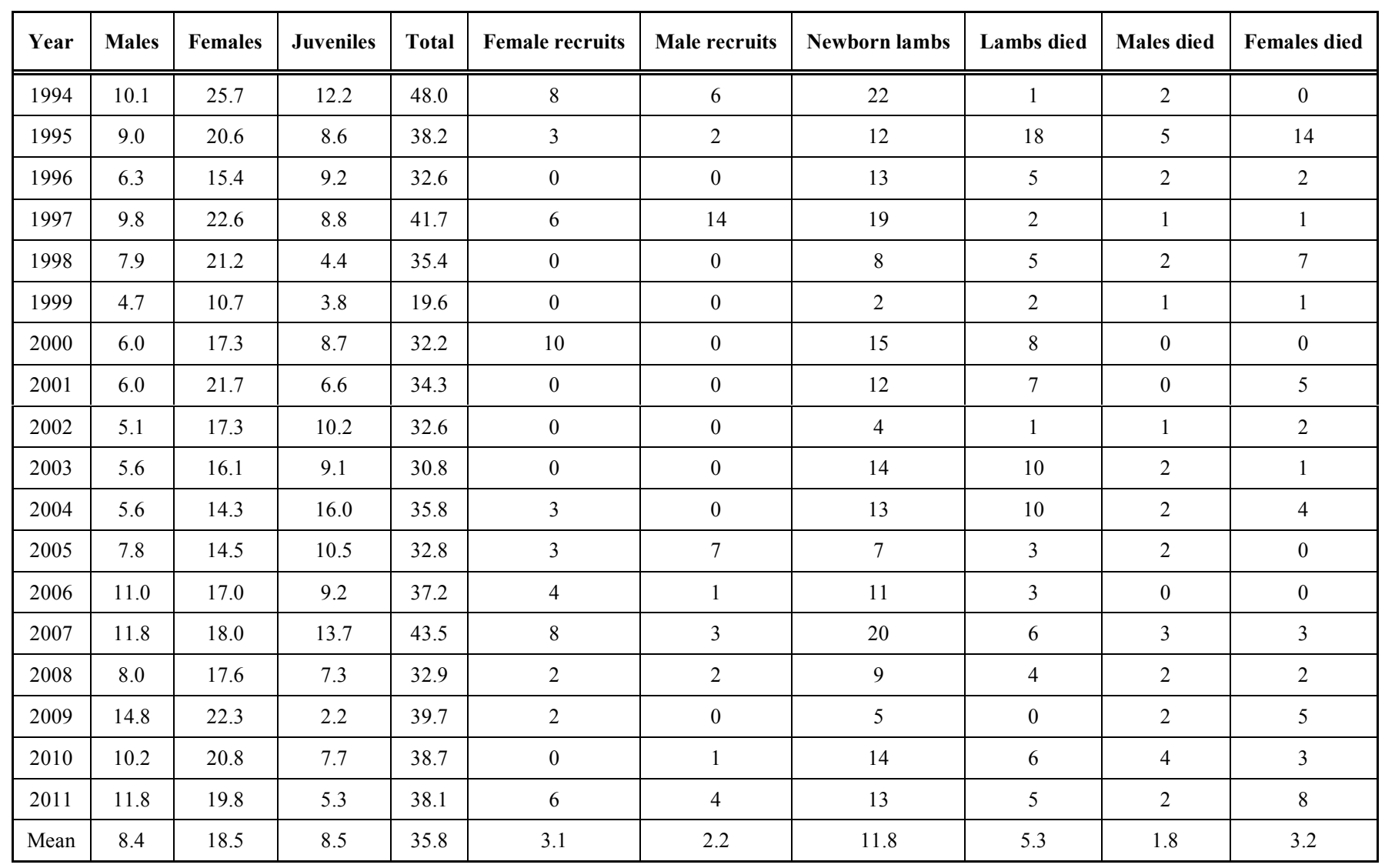

females compared to only 5 males during 2001-2004 distorted sex ratio in favour of males during 2000-2001. Thereafter sex ratio became progressively unbalanced in favour of females during 2001-2004. The recruitment of 7 males compared to only 3 females further skewed sex ratio towards males in 2005 (Fig. 4a).

The births of 213 lambs were recorded during 19942011. The births occurred all year round but were slightly more during the early rains in January-March when forage quality peaks (Fig. 4b). Contrasts of adjusted least square means of birth rate confirmed that births were aseasonal and occurred all year round $\left(F_{11,193}=0.44, P=0.9343\right.$, Fig. 4 b) . The observed monthly distribution of birth rates during 1994-2011 revealed considerable interannual variation, in correspondence with marked interannual variation in the seasonal distribution of rainfall (Fig. 5a). Birth rate varied alternatingly, exceeding the overall average of 5.3 lambs per 100 females per year for one to two years and then falling below average for another one to two years during 19942011 (Fig. 5a).

Juvenile recruitment was the lowest in the two years with the highest rainfall, namely 1998 and 2001, but the highest in 2004 and 2007 with good rainfall (Table 1, Fig. 5b). Besides 2007 with very high rainfall, female recruitment was also highest in years with average (1994) and exceptionally low
(1997 and 2000) rainfall (Table 1, Fig. 5c). Male recruitment was the highest in years with the lowest dry season rainfall, specifically 1994, 1997 and 2005 (Table 1, Fig. 5d).

Of the total of 213 lambs born during 1994-2011, 96 (45.1\%) died within a month of birth. Furthermore, the numbers of recorded deaths of females $(n=58)$ and males $(n$ $=33$ ) were extremely high relative to the numbers of females $(n=55)$ and males $(n=40)$ surviving to at least 6 months of age in the same period. Lamb mortality was the lowest in April, when rainfall is the highest and food quality is still high due to new grass growth, but was the highest in January-February and July-August, when rainfall is the lowest (Figs. 1b and 4c). The mortality of all impalas regardless of age, or sex, peaked in 1995 due to tick infestation. In addition, lamb mortality was notably high in 2003-2004 whereas female mortality was also high in 1998 and 2001, with exceptionally high rainfall (Table 1, Fig. 5e). The extreme drought in 2000 was associated with elevated mortality of lambs (Fig. 5e) but not of the older females (Fig. $\mathbf{5 g}$ ) or males (Fig. 5h). Even so, the average mortality amounted to merely $2.3 \%(\% \mathrm{CV}=66.8)$ of the total impala population each year (Fig. 5f). Of this, lambs made the greatest contribution (mean $=51.9 \%$ ) whereas males $(21.7 \%)$ and females $(26.5 \%)$ made smaller but similar contributions (Table 2). Recorded causes of impala mortalities ranged from injuries, severe trauma, internal hemorrhage and 

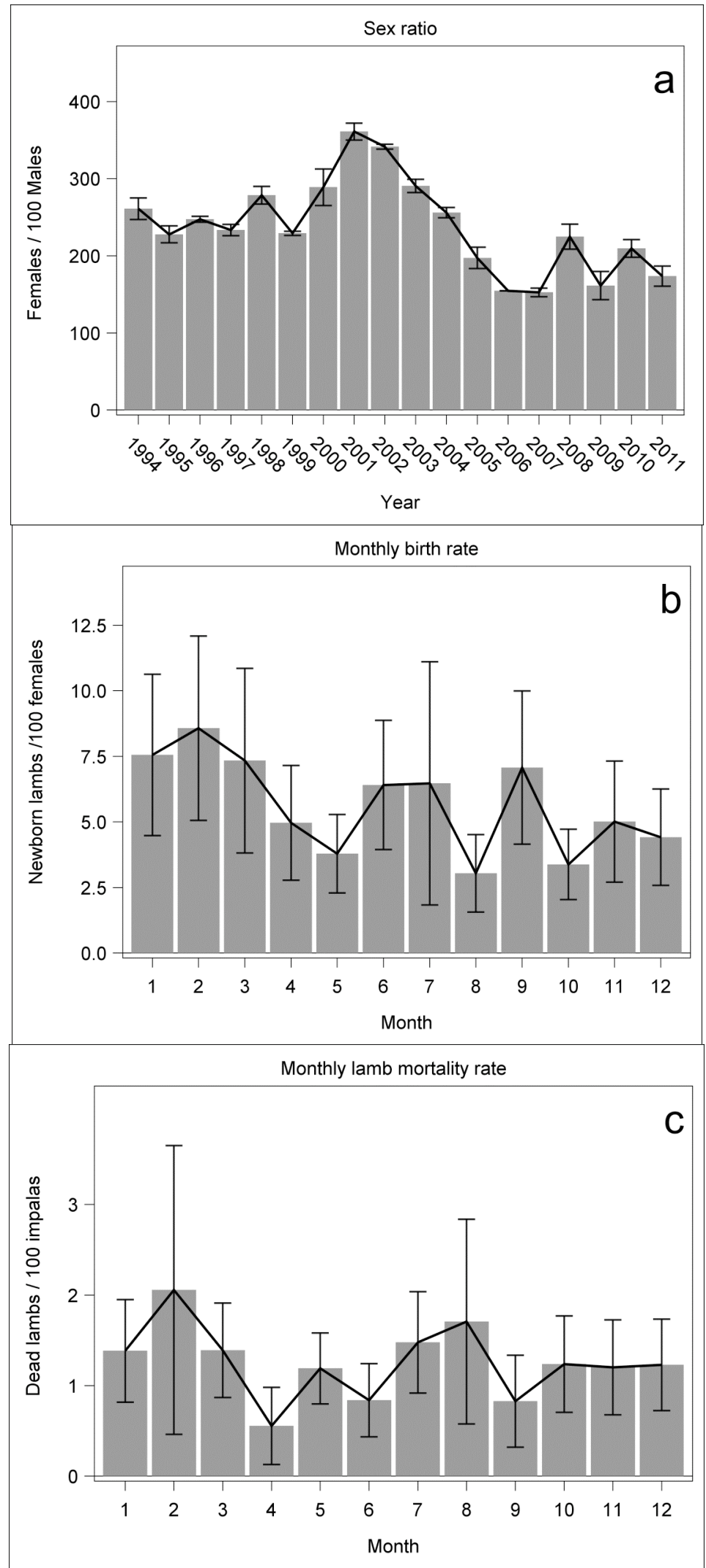

Fig. (4). The variation in sex ratio (a), monthly birth rate (b) and lamb mortality rate (c) during June 1994-December 2011 and the associated mean (solid line) and standard error (capped vertical lines).

shock arising from male-male fights $(n=9$ males), injuries such as those caused by fence wires $(n=4$ lambs, 4 females and 1 male), diseases ( $n=5$ females and 1 lamb), predation by pythons (Python sebae, $n=1$ female, 1 male and 1 lamb) and jackals (Canis mesomelas, $n=3$ lambs), senescence ( $n=$ 2 females) and snake bite ( $n=1$ female). 
Table 2. The Percentage of the Total Impala Population Dying each Year and the Percentage Contribution to the Total Mortality by Females, Males and Lambs during June 1994-December 2011

\begin{tabular}{|c|c|c|c|c|}
\hline Year & Total (\%) & Females (\%) & Males (\%) & Lambs (\%) \\
\hline \hline 1994 & 0.9 & 0.0 & 66.2 & 33.8 \\
\hline 1995 & 7.3 & 36.2 & 11.9 & 51.9 \\
\hline 1996 & 2.4 & 23.2 & 23.5 & 53.3 \\
\hline 1997 & 0.9 & 21.8 & 27.2 & 51.1 \\
\hline 1998 & 3.2 & 50.2 & 12.6 & 37.2 \\
\hline 1999 & 1.6 & 24.3 & 24.3 & 51.5 \\
\hline 2000 & 1.9 & 0.0 & 0.0 & 100.0 \\
\hline 2001 & 2.7 & 41.3 & 0.0 & 58.7 \\
\hline 2002 & 1.0 & 50.4 & 24.4 & 25.2 \\
\hline 2003 & 3.1 & 7.6 & 16.1 & 76.4 \\
\hline 2004 & 3.6 & 24.5 & 13.0 & 62.5 \\
\hline 2005 & 1.2 & 0.0 & 37.4 & 62.6 \\
\hline 2006 & 0.6 & 0.0 & 0.0 & 100.0 \\
\hline 2007 & 2.3 & 24.9 & 24.9 & 50.3 \\
\hline 2008 & 1.9 & 24.6 & 27.1 & 48.3 \\
\hline 2009 & 1.4 & 71.5 & 28.5 & 0.0 \\
\hline 2010 & 2.6 & 24.2 & 30.9 & 44.9 \\
\hline 2011 & 3.3 & 53.5 & 13.5 & 33.0 \\
\hline Mean & 2.3 & 26.6 & 21.2 & 52.3 \\
\hline$\% C V$ & 66.5 & 78.6 & 74.2 & 46.1 \\
\hline
\end{tabular}

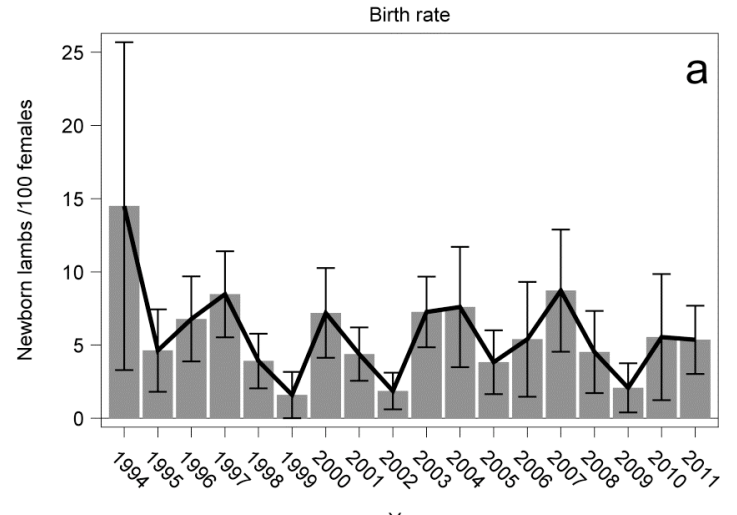

Year

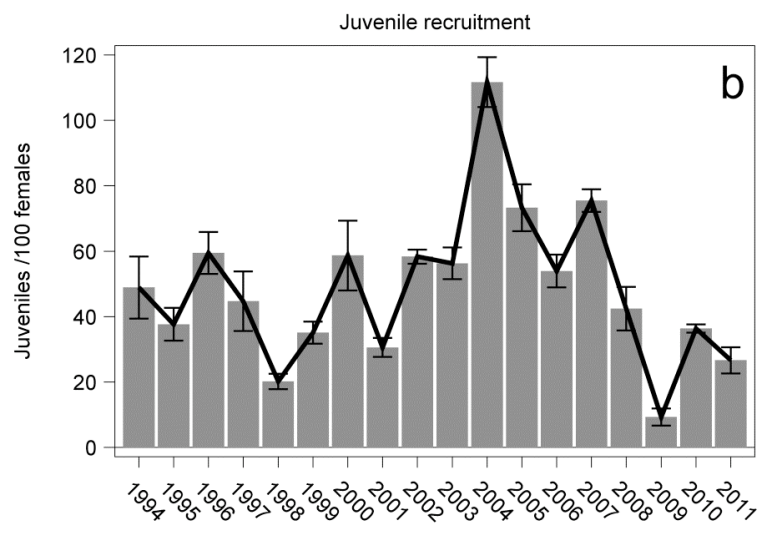

Year
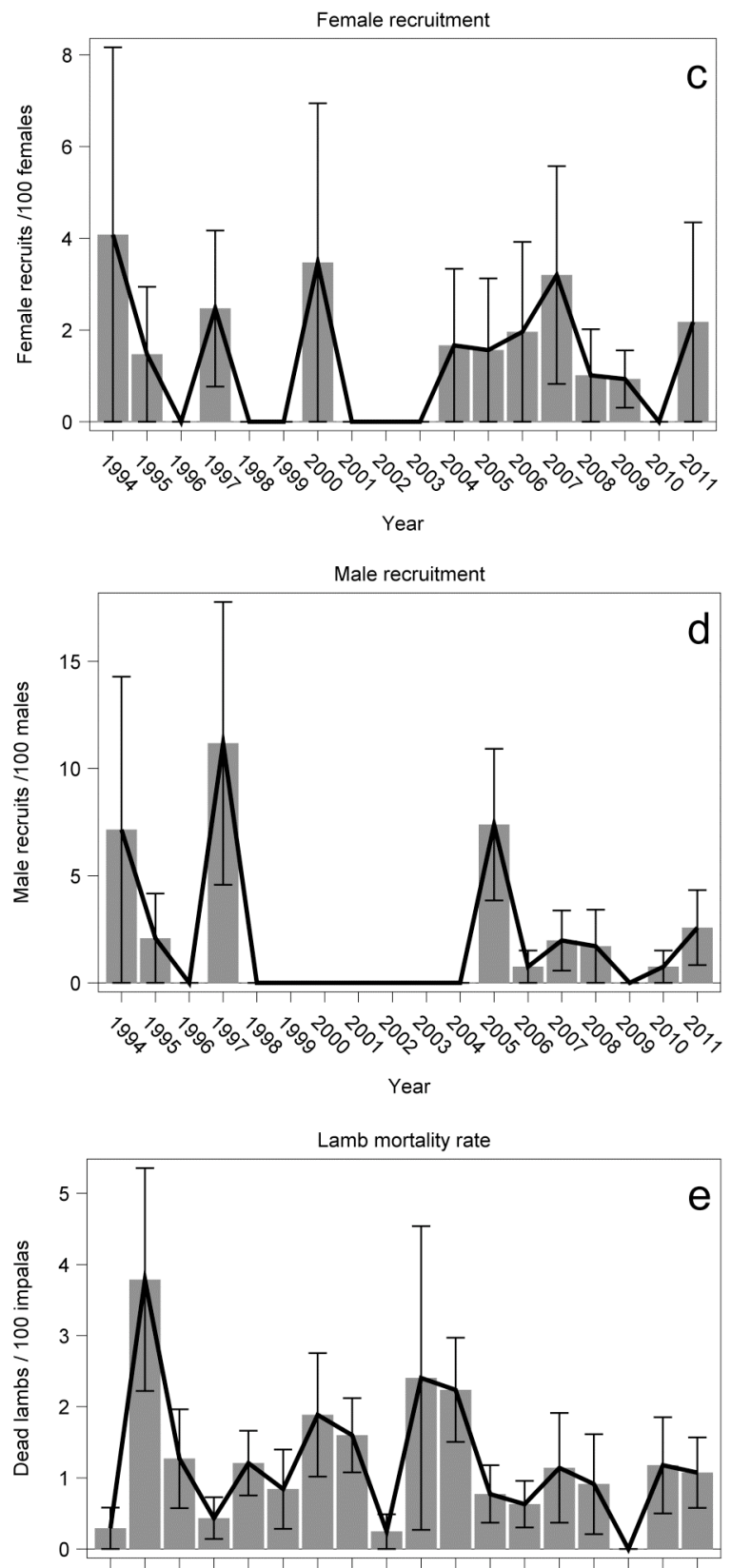

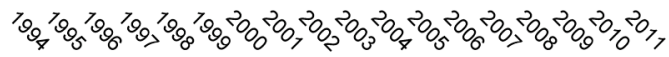

Year

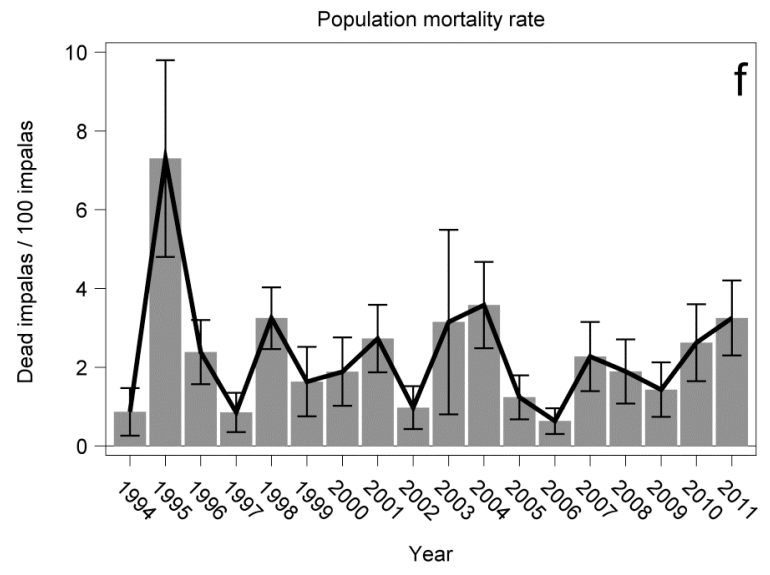

Fig. (5) Contd.....

Fig. (5) Contd..... 

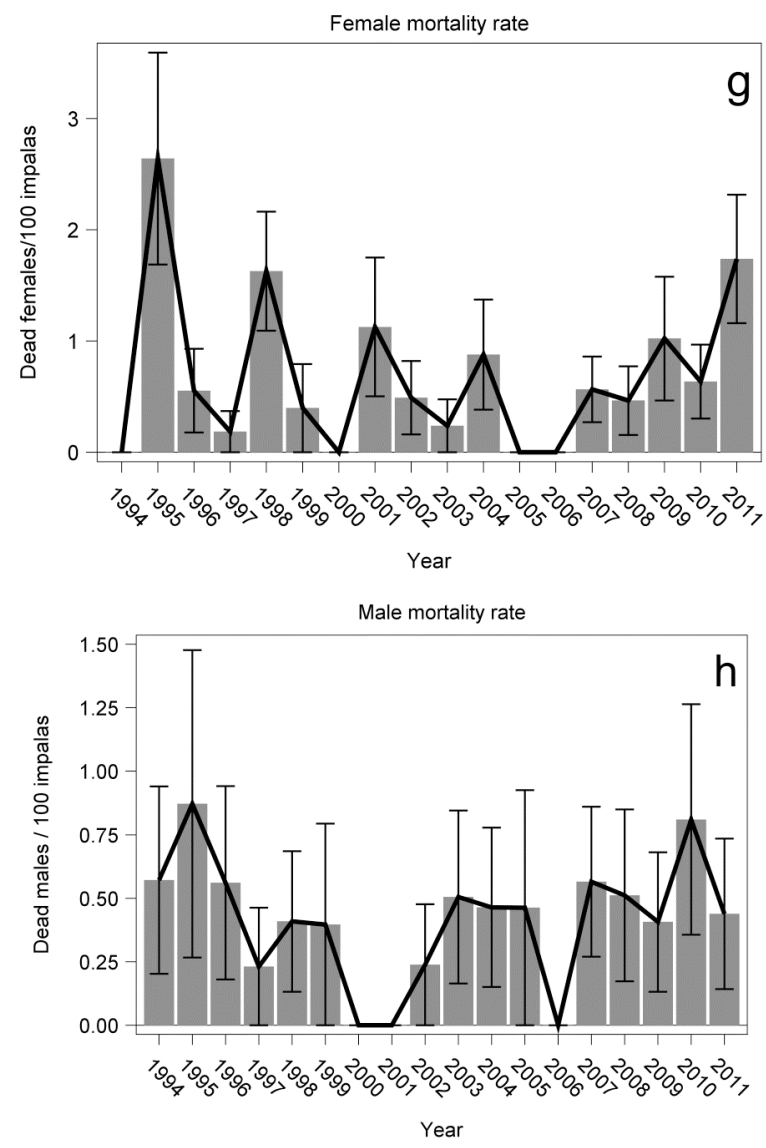

Fig. (5). The variation in the annual averages of birth rate (a), juvenile (b), female (c) and male (d) recruitment rates and lamb (e), population (f), female (g) and male (h) mortality rates during June 1994-Decemeber 2011 and the associated mean (solid line) and standard error (capped vertical lines).

\section{Rainfall, Density and Temperature Influences}

Birth rate decreased with increasing rainfall averaged over 4-8 months before the birth month (Fig. 6a, $F_{1,10}=4.66$, $P=0.0562)$ and with the 5-year running mean of the annual rainfall (Fig. 6e, $F_{1,16}=7.51, P=0.0152$ ). The ratio of females to males (sex ratio) decreased marginally with increase in the 6-month moving average of the monthly rainfall (Fig. 6b, $F_{1,10}=3.47, P=0.0921$ ) but increased with increase in the 5-year running mean of the wet season rainfall (Fig. 6f, $F_{1,16},=3.40, P=0.0837$ ). Juvenile recruitment increased with increase in the 5-month running mean of monthly rainfall (Fig $\mathbf{6 c}, F_{1,10}=4.80, P=0.0533$ ) but was little affected by the current annual rainfall (Fig. 6g, $F_{1,16}=$ $1.31, P=0.2711$ ). Mortality rate of newborn lambs (Fig. 6d, $\left.F_{1,10}=10.56, P=0.0087\right)$ and the overall population mortality rate (Fig. 6h. $F_{1,10}=3.67, P=0.0844$ ) was high in months with low rainfall. High female (Pearson $r=0.412, P$ $=0.100)$ and male $(r=0.440, P=0.0773)$ mortality rates were associated with high current wet season rainfall. However, female $(r=0.618, P=0.0108)$, male $(r=0.692, P$ $=0.0030)$ and population $(r=0.4515, P=0.0792)$ mortality rates were positively correlated with population abundance in the preceding year. The ratio of juveniles to females $(r=$ $-0.5106, P=0.0433)$, sex ratio $\left(r_{s}=-0.525, P=0.0366\right)$ and birth rate $(r=-0.411, P=0.114)$ were negatively correlated with prior abundance but lamb mortality rate $(r=0.099, P=$ 0.716 ) was not.

Maximum temperature was significantly correlated with female mortality, juvenile recruitment and sex ratio after partialling out the effect of rainfall. More precisely, hot, wet seasons were associated with elevated female mortality whereas hot, dry seasons with reduced juvenile recruitment (Table 3). The increased mortality of females in hot, wet seasons was associated with increased overall impala population mortality in hot, wet seasons (or years, Table 3) and reduced sex ratio (Pearson correlation coefficient between maximum wet season temperature and sex ratio after partialling out wet season rainfall $=-0.54453, P=$ 0.0292).

\section{DISCUSSION}

Temporal Trends in Abundance, Sex Ratio, Birth, Recruitment and Mortality Rates

The impala population size fluctuated considerably due to intrinsic variation in births and mortalities, particularly due to an outbreak of tick attacks in 1995, ENSO floods in 1998 and heavy rains in 2001. Differential timing and disparities in the number of male and female recruitment and mortality events were associated with deviation in sex ratio from parity. In particular, more females than males were recruited during drought years when resources were scarcest (e.g., in 2000). However, sex ratio was biased towards males when rainfall had been high in the past six months, consistent with the prediction of the Trivers \& Willard (1973) model of optimal sex ratio adjustment that, among polygynous species, mothers in poor condition should produce offspring with sex ratios biased towards females, whereas mothers in good condition should do the opposite. But when the 5-year running mean of wet season rainfall had been high, sex ratio was unbalanced in favour of females, apparently contradicting the prediction of the Trivers and Willard (1973) model. This apparent contradiction is resolved if the increase in the cumulative past rainfall is presumed to have reduced habitat suitability for impalas as expected by rainfall-forage quality relations. These findings are tentative due to the very low numbers of females in the Sanctuary and the fact that sex ratios of offspring in ungulates are strongly affected by population size (FestaBianchet \& Côte 2008). Even so, they do suggest that high rainfall is favourable to impalas in the short term (0-5 months) but not over extended periods, as measured by the 5-year moving average, because this likely shifts the vegetation state a way from the optimum for female impala, by increasing woody cover (Sanakran et al. 2005), grass height and biomass (Sinclair 1975, McNaughton 1985, Boutton 1988a). Although it is parity at birth but skewed towards females at maturity (Fairall 1983), impala sex ratio varied widely and the bias in favour of females was sometimes reduced and became minor in years with hot, wet seasons.

Births were aseasonal but somewhat more occurred during the January-March period soon after the short rains in November-December when plant growth is vigorous and quality peaks in African savannas grasses (Tolsma et al. 
1987, Boutton et al. 1988b, Prins \& Beekman 1989). The aseasonal birth pattern is consistent with the high local rainfall and hence plant productivity and year-round availability of drinking water, and with observations of year-
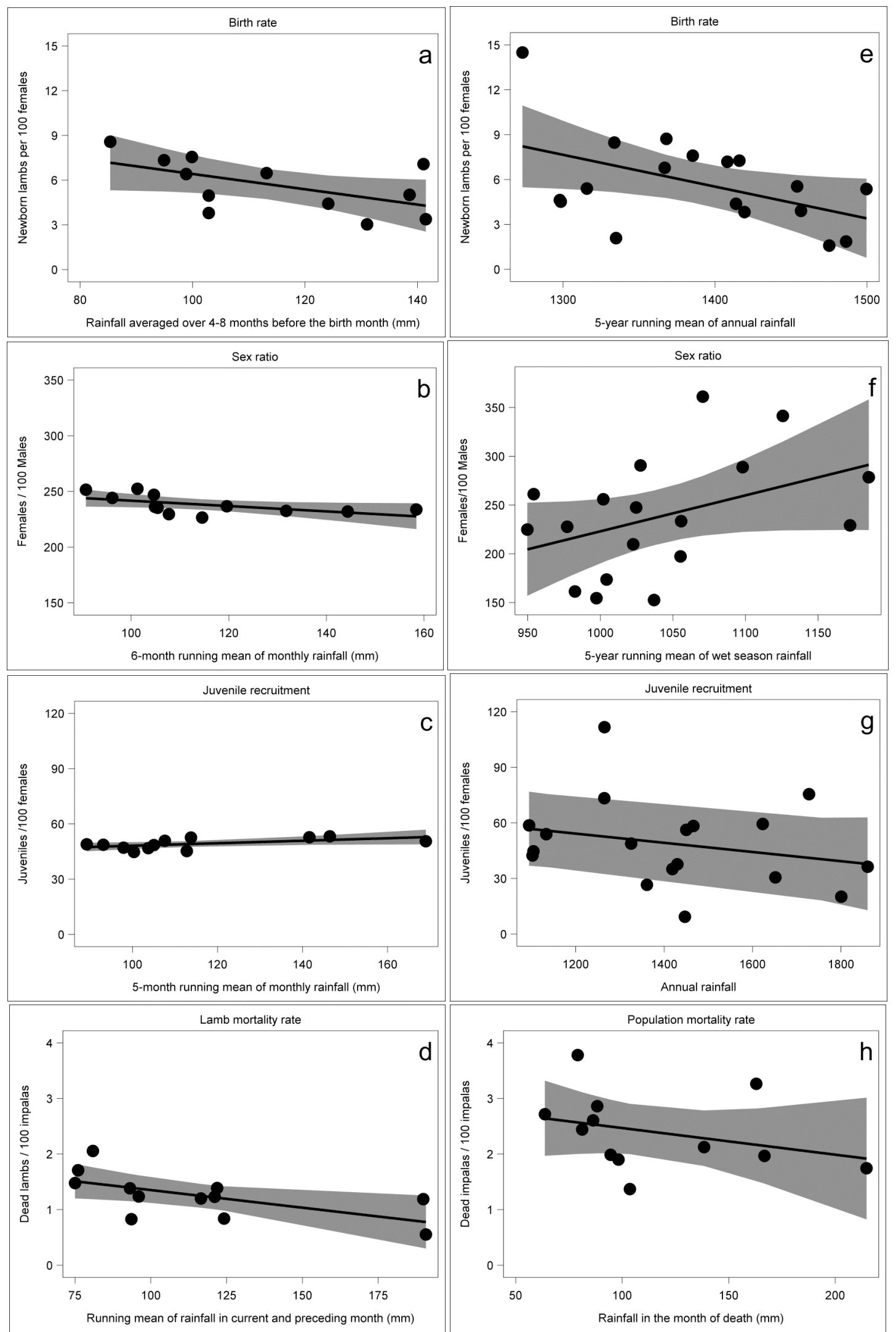

Fig. (6). Linear regression relationships between birth rate (a and $\mathbf{e})$, sex ratio (b and $\mathbf{f})$, juvenile recruitment (c and $\mathbf{g})$, lamb mortality rate (d), and population mortality rate (h) and moving averages of monthly, seasonal and annual rainfall and the associated $95 \%$ point wise confidence bands for the fitted lines. 
Table 3. Spearman Rank Correlations between Impala Demographic Rates and Standardized Mean Seasonal Maximum (MaxWet and Max Dry) and Minimum (MinWet and MinDry) and Annual Maximum (MaxAnnual) and Minimum (MinAnnual) Temperatures after Partialling Out the Corresponding Seasonal (annual) Rainfall Components. Significant Coefficients and their Associated P-Values (P-Value) are Highlighted in Bold Face

\begin{tabular}{|c|c|c|c|c|c|c|c|}
\hline $\begin{array}{c}\text { Temperature } \\
\text { component and P-value }\end{array}$ & $\begin{array}{c}\text { Juvenile } \\
\text { recruitment rate }\end{array}$ & $\begin{array}{c}\text { Female } \\
\text { mortality rate }\end{array}$ & $\begin{array}{c}\text { Male } \\
\text { mortality rate }\end{array}$ & $\begin{array}{c}\text { Lamb } \\
\text { mortality rate }\end{array}$ & $\begin{array}{c}\text { Population } \\
\text { mortality rate }\end{array}$ & $\begin{array}{c}\text { Sex } \\
\text { ratio }\end{array}$ & $\begin{array}{c}\text { Birth } \\
\text { rate }\end{array}$ \\
\hline \hline MaxWet & -0.101 & $\mathbf{- 0 . 6 8 8}$ & 0.1780 & -0.421 & $-\mathbf{0 . 6 4 9 6}$ & -0.347 & -0.041 \\
\hline P-value & 0.7101 & $\mathbf{0 . 0 0 3 2}$ & 0.5058 & 0.1049 & $\mathbf{0 . 0 0 6 5}$ & 0.1884 & 0.8816 \\
\hline MinWet & -0.181 & -0.346 & -0.261 & -0.374 & -0.4300 & 0.2734 & -0.065 \\
\hline P-value & 0.5020 & 0.1897 & 0.3294 & 0.1538 & 0.0965 & 0.3055 & 0.8097 \\
\hline MaxDry & $\mathbf{- 0 . 5 3 5}$ & -0.083 & -0.280 & -0.263 & -0.2991 & 0.0296 & -0.297 \\
\hline P-value & $\mathbf{0 . 0 3 2 7}$ & 0.7615 & 0.2949 & 0.3252 & 0.2605 & 0.9133 & 0.2642 \\
\hline MinDry & -0.476 & -0.050 & -0.310 & 0.153 & 0.0151 & -0.096 & -0.325 \\
\hline P-value & 0.0622 & 0.8544 & 0.2431 & 0.5711 & 0.9557 & 0.7235 & 0.2194 \\
\hline MaxAnnual & -0.450 & -0.335 & -0.026 & -0.423 & $-\mathbf{0 . 5 3 4 1}$ & -0.3406 & -0.272 \\
\hline P-value & 0.0803 & 0.2041 & 0.9239 & 0.1023 & $\mathbf{0 . 0 3 3 1}$ & 0.1967 & 0.3078 \\
\hline MinAnnual & -0.367 & -0.480 & -0.443 & -0.244 & -0.4849 & 0.2925 & -0.193 \\
\hline P-value & 0.1616 & 0.0598 & 0.0859 & 0.3626 & 0.0570 & 0.2716 & 0.4737 \\
\hline
\end{tabular}

round breeding in other populations of the east African impala (Sinclair et al. 2000, Moe et al. 2007, Ogutu et al. 2011). The small, albeit insignificant, bulge observed in births during the early rains is consistent with timing peak births to match peaks in forage quality to satisfy the high energetic demands of late pregnancy and early lactation and rapid early lamb growth (Sadleir 1969, Oftedal 1985). The negative associations of birth rate with high rainfall during the conception and gestation periods and with increasing 5year running mean of annual rainfall suggest negative effects of high rainfall operating through reduced nutritional quality of grasses due to accumulation of structural carbohydrates (fibers) in secondary cell walls that are much more resistant to digestion and hence dilute nutrient concentrations (Bouton et al. 1988b, Georgiadis and McNaughton 1990). Besides taller and poorer quality grass, high rainfall during the 5-year rainfall cycles in this high rainfall region likely alters habitat suitability for impalas by causing more frequent water logging and reducing food availability through restricted access to the low-lying lake shore grasslands, thereby elevating risks of diseases and pathogens and leading to fewer births. Not surprisingly, births were fewer in exceptionally wet years (e.g. 1998) further reinforcing the notion that excessive rainfall causes flooding and lowers forage quality (Fryxell 1995), enhances the activities of parasites, while increasing the vulnerability of herbivores to parasites and diseases, such as parasitic pneumonia and tick-born diseases observed for this impala population after floods, and anthrax outbreaks reported for other impala populations after droughts (Prins \& Weyerhaeuser 1987, Wafula et al. 2007).

Juvenile recruitment was reduced in years with unusually high rainfall (e.g. 1998 and 2001) and hot dry seasons, implicating the influences of both lowered forage quality and increased vulnerability to diseases and parasites, but peaked in years with good rainfall (e.g. 2004 and 2007). Also, juvenile recruitment increased when rainfall in the past five months had been high but was less sensitive to variation in annual rainfall, suggesting greater sensitivity to recent changes in nutritional sufficiency of forage. In contrast to females, male recruitment peaked when dry season rainfall was highest; implying that female impalas give birth to and successfully wean more males in dry periods with higher food availability, but female recruitment was high in some high as well low rainfall years.

On average, natural mortality rate was remarkably low and removed merely $2.3 \%$ of the total population annually, mostly due to the mortality of newborn lambs, a rate evidently much lower than those recorded for more wide ranging impalas subject to predation by large carnivores (e.g. Cronje et al. 2002). But similarly high mortalities in the early months of life have also been reported for some wild impala populations (Fairall 1983). Males and females made lesser but similar contributions to overall mortality. Lamb mortality was the lowest in the wettest month (April) when food availability is still high (Boutton et al. 1988b). However lamb and population mortalities were elevated in dry months, with greater food scarcity. Moreover, lamb mortality was elevated during extreme droughts further implicating the role of starvation, but female mortality peaked in the wettest years (e.g. 1998) and also increased in hot, wet seasons, suggesting heightened susceptibility to diseases and parasites. Mortalities of newborn lambs and individuals of all age classes were elevated in low-rainfall months, further implicating food scarcity. The relatively small size of the Sanctuary and its complete fencing means that impalas cannot move anywhere else where there is more or better-quality food available during unfavourable periods, thus amplifying their vulnerability to food scarcity, flooding, diseases and parasites linked to rainfall and temperature fluctuations compared to populations occupying unfenced or fenced but larger areas. Female and male mortality rates also increased in wetter, wet seasons, in accord with the expectation that high 
rainfall lowers forage quality due to greater dilution of plant nutrients by fibres (Boutton et al. 1988b, Georgiadis \& McNaughton 1990), increases the risk of diseases and promotes activities of pathogens.

The inverse density-dependence of juvenile recruitment, female, male and population mortality rates, implicate population limitation mediated through negative feedbacks of prior density on per capita food availability. Consequently, the negative density dependence implies that impalas compete more strongly for restricted resources at higher densities (Gaidet \& Gaillard 2008). Inversely density-dependent recruitment pattern has also been documented for an impala population in Zimbabwe (Gaidet \& Gaillard 2008). Densitydependent responses have also been widely documented for populations of many other African ungulate species, including for buffalo (Syncerus caffer, Sinclair 1977) and wildebeest (Connochaetes taurinus, Mduma et al. 1999) in MaraSerengeti, impala, giraffe (Giraffa camelopardalis) and zebra (Equus burchelli) in Kruger National Park (Ogutu \& Owen-Smith 2003) and in zebra and giraffe in Laikipia in Kenya (Georgiadis et al. 2007). Due to the small size of the Sanctuary, we expected competition among impalas for food and space to intensify with increasing population size, leading to sporadic population crashes. Yet, despite strong fluctuations in population size, the impala population did not collapse during 1994-2011 as predicted. This implies that, though very small, the Impala Sanctuary maintains high functional habitat diversity and productivity, which is further enhanced by managerial interventions, including periodic burning of moribund grasslands and slashing of the lakeside reeds, rushes and sedges. High density can also elevate stress levels and compromise the immune function of ungulates, amplifying their susceptibility to parasites, the severity of otherwise inconsequential infections and the risk of mortality of animals inhabiting small reserves (Ezenwa 2004), such as the Kisumu impala population.

High ambient maximum temperatures can directly constrain the activities of impala, including their foraging time (Klein \& Fairall 1986), affect their thermoregulation and water turnover (Maloiy \& Hopcraft 1971), increase desiccation of forage and evaporation of surface drinking water. Impalas are most active when ambient temperatures range between 22 and $31{ }^{\circ} \mathrm{C}$ and reduce activity levels when maximum temperatures exceed $31{ }^{\circ} \mathrm{C}$ (Klein \& Fairall 1986). From June 1994 to December 2011 the average maximum monthly temperature exceeded $31{ }^{\circ} \mathrm{C}$ during $17.5 \%$ and 32 ${ }^{\circ} \mathrm{C}$ during $7 \%$ of the time ( $n=211$ months). Maximum temperatures exceeded $32{ }^{\circ} \mathrm{C}$ almost exclusively during December-March. The high maximum temperatures almost certainly reduced daytime activity levels of impalas. Similarly to impala, activity levels of the giraffe (Leuthold and Leuthold 1978), eland (Taurotragus oryx, Lewis 1977) and blesbok (Damaliscus dorcas, Klein \& Fairall 1986) were reduced when maximum temperature exceeded $32{ }^{\circ} \mathrm{C}$ whereas the greater kudu (Trageplaphus strepsiceros, OwenSmith 1998) reduced their activities when temperature exceeded $36{ }^{\circ} \mathrm{C}$. The increased mortality of female impalas in hot, wet seasons suggests increased susceptibility to parasites and diseases in hot, damp weather conditions whereas the reduced juvenile recruitment during hot, dry seasons suggests paucity of food due to habitat desiccation exacerbated by high ambient temperatures. The woodland vegetation in the Sanctuary that remains green all year, proximity to permanent lake water and high rainfall ameliorate the severity of maximum temperature influences on impalas during droughts and dry seasons.

\section{Causes of Impala Mortality}

Most impala mortalities were linked to parasites, most notably the outbreak of tick-borne diseases in 1995. Other recorded sources of mortality, including male fights, fatal accidents, predation, snake bites and senescence made minor contributions to the total mortality. The negligible contribution of male fights to the total mortality is very surprising given the small size of the sanctuary. However, in large protected areas supporting many large predators, predation has been reported as the leading source of impala mortality, with male fights contributing less than $2 \%$ to total mortality (Cronje et al. 2002).

Restricted movement, limited resource availability and disruption of social structure associated with confinement in small, fenced reserves, by acting as stressors (Enzenwa 2004), apparently predisposed the impalas periodically to high parasite loads, notably of ticks and worms, which in turn predisposed the impalas to other mortality agents, especially diseases. Thus, for example, in December 1992 before the regular counts began, KWS veterinarians prepared postmortem reports showing that impalas suffered from heavy worm infestation, especially after the onset of heavy rains, as has also been documented for other impala populations inhabiting African savannas (Ocaido et al. 1999; Nalubamba et al. 2011). Worm infestation also featured alongside ticks in many other postmortem reports, most preeminently in 1993 and 1995. On 19 January 1993, postmortem examinations carried out on two impalas found the cause of the death of one of them to be verminous (parasitic) pneumonia, which caused consolidation of over $60 \%$ of the lung tissue and pale yellow firm swellings diffusely distributed in the lung tissue. Other pathological findings included lung and liver lesions. Blood serum analysis indicated raised tissue enzymes, hypoprotemia, indicating pneumonia and debility. The observed high parasite loads are not necessarily typical for populations inhabiting small fenced areas alone since several other studies have noted similarly high or higher incidences of parasites in impala populations occupying large protected areas across Africa. Thus, lungworms (Pneumostrongylus calcaratus) were found in $85 \%$ of impalas in the $230 \mathrm{~km}^{2}$ Mlawula Nature Reserve in Swaziland where the worm poses no serious threat to the health of impalas (Gallivan et al. 1989). Also, extremely high incidences of verminous pneumonia were reported in impala and other ungulate species in an area bordering the Serengeti National Park in Tanzania, caused by five different lungworm species of the family protostronglylidae, including $P$. calcaratus but the ungulates surprisingly showed no clinical signs of disease (Moulton \& Sachs 1970).

Furthermore, unusually many impalas died in 1995 primarily due to tick-borne diseases. In February 1995, the weather was hot (mean daily maximum temperature was $30.7^{\circ} \mathrm{C}$ ) and humid and impalas were attacked by many ticks. As well, plentiful rainfall throughout April $(292.2 \mathrm{~mm})$ and May $(171.1 \mathrm{~mm}) 1995$ led to very tall grass growth. Thus, besides the tick attacks, impala had difficulty feeding 
on the tall grass and moving around as the whole Sanctuary was wet and muddy. This precipitated the deaths of 37 impalas (18 lambs, 14 females and 5 males). Examinations of blood and lung smears and faecal samples on 17 May 1995 by the KWS veterinary doctors found the faecal samples to be positive for worms and that the impalas suffered from septicaemia, theileriosis ( $T$. annulata), a protozoan and tick-borne disease found typically among cattle, and helmithiasis. On 21 June 1995, a female impala died immediately after giving birth. Two young impalas soon died afterwards, one on 23 June 1995 and the other on 30 June 1995 primarily due to the heavy tick infestation. By June 1995 rainfall had reduced $(83.3 \mathrm{~mm})$ but the grass was still very tall and green. Conditions became progressively drier towards the end of July $(78 \mathrm{~mm})$ 1995. Seven impalas that were already in poor body condition died. In August 1995, 16 more impalas died, leaving only 29 impalas, which were also in poor health.

A postmortem carried out on a dead impala with a history of weakness and profuse diarrhea on 30 August 1995, also identified theileirosis as the cause of death. The impala was in good body condition but anaemic; the anal area was covered with greenish diarrhea, the lungs had ecchinococcus granulosa cysts, blood smear revealed erythrocytic piroplasms in different forms - rods, round and comma shaped. Finally, the lymph nodes were small and congested at the time of death. The Sanctuary management decided to burn the moribund grass to reduce tick prevalence. The first burning exercise took place on the grasslands on 31 August 1995. Impalas continued to die despite the various measures taken. Again, during and following the El Niño floods of December 1997 to January-June 1998, 14 impalas died in 1998 including 5 lambs, 7 females and 2 males.

In conclusion, although it fluctuated markedly and was strongly related to the overall mortality, variation in juvenile recruitment contributed little to the overall impala population dynamics as expected for large herbivores (Sinclair 1977, Owen-Smith 1990, Mduma et al. 1999). Juvenile recruitment showed a humped relationship with rainfall and was dep- ressed during hot dry seasons and excessively wet periods. Also, adult survival had lower interannual variation than juvenile recruitment, which typically varies widely among ungulates due to various factors (Owen-Smith et al. 2005). Adult survival, which has larger effect on overall population dynamics, was more resistant to changing environmental conditions, consistent with expectation (Mduma et al. 1999, Albon et al. 2000, Gaillard et al. 2000, Owen-Smith \& Mason 2005). Sex ratio was often skewed towards females, due to sex-specific differences in the influence of prior rainfall on recruitment and was lowered in hot, wet seasons due to heightened female mortality. Excessive rainfall, especially when coupled with high temperatures, created adverse conditions for impalas, precipitating high mortalities. Since mortality was also high at low rainfall values, the results therefore suggest a humped relationship between impala population abundance and rainfall. The negative effect of high prior density on population growth was manifested through higher overall and sex-specific mortality rates and resulted in lower sex ratios $(\mathrm{F}: \mathrm{M})$ and birth rates at higher prior densities. These findings provide insights useful for understanding dynamics of herbivores, especially those occupying small habitat fragments expected to become more common as a consequence of habitat fragmentation and isolation due to widespread and intensifying land use changes.

\section{CONFLICT OF INTEREST}

None declared.

\section{ACKNOWLEDGEMENTS}

We thank the Kenya Wildlife Service for permission to use these data. Pauline Okode, Isaac Kibet and Linah Jerono were primarily responsible for the impala counts in the Kisumu Impala Sanctuary between June 1994 and December 2011. Felix Ogutu, Christopher Nyaware, Seneca Odhiambo, Fredrick Lala and Timothy Ikime assisted with accessing the impala counts.

\section{Appendix}

Table A1. Values of the Corrected Akaike Information Criterion Used to Select between Models Relating Lagged Rainfall Components and Demographic Characteristics of the Kisumu Impala Population. The Selected Best Models are Highlighted in Bold Face Font

\begin{tabular}{|c|c|c|c|c|c|c|c|}
\hline Period & $\begin{array}{c}\text { Lagged Rainfall } \\
\text { component }\end{array}$ & Birth rate & $\begin{array}{c}\text { Recruitment } \\
\text { rate }\end{array}$ & $\begin{array}{c}\text { Lamb mortality } \\
\text { rate }\end{array}$ & $\begin{array}{c}\text { Population mortality } \\
\text { rate }\end{array}$ & Sex ratio & $\begin{array}{c}\text { Population } \\
\text { abundance }\end{array}$ \\
\hline \hline Monthly & Mavrain1 & & 66.0 & 16.5 & $\mathbf{3 1 . 7}$ & 93.0 & \\
\hline & Mavrain2 & & 65.1 & $\mathbf{1 4 . 4}$ & 32.6 & 93.1 & \\
\hline & Mavrain3 & & 65.0 & 14.5 & 32.8 & 93.2 & \\
\hline & Mavrain4 & & 63.1 & 16.0 & 33.0 & 93.1 & \\
\hline & Mavrain5 & & $\mathbf{6 2 . 5}$ & 16.2 & 32.9 & 91.2 & \\
\hline & Mavrain6 & & 64.8 & 14.5 & 33.0 & $\mathbf{8 8 . 9}$ & \\
\hline
\end{tabular}


(Table A1) Contd....

\begin{tabular}{|c|c|c|c|c|c|c|c|}
\hline Period & $\begin{array}{l}\text { Lagged }{ }^{\dagger} \text { Rainfall } \\
\text { component }\end{array}$ & Birth rate & $\begin{array}{l}\text { Recruitment } \\
\text { rate }\end{array}$ & $\begin{array}{l}\text { Lamb mortality } \\
\text { rate }\end{array}$ & $\begin{array}{l}\text { Population mortality } \\
\text { rate }\end{array}$ & Sex ratio & $\begin{array}{l}\text { Population } \\
\text { abundance }\end{array}$ \\
\hline \multirow[t]{3}{*}{ Annual } & Mavannual1 & 97.7 & 170.2 & 54.6 & 71.9 & 204.8 & 118.2 \\
\hline & Mavannual3 & 96.8 & 170.2 & 54.5 & 72.7 & 204.5 & 114.5 \\
\hline & Mavannual4 & 95.3 & 171.1 & 54.6 & 73.1 & 203.0 & 112.8 \\
\hline \multirow[t]{3}{*}{ Dry season } & Mavdry 1 & 97.2 & 170.0 & 54.7 & 73.0 & 204.9 & 118.4 \\
\hline & Mavdry2 & 96.9 & 170.7 & 54.5 & 73.5 & 204.9 & 118.4 \\
\hline & Mavdry3 & 97.9 & 170.2 & 54.5 & 73.5 & 205.1 & 118.3 \\
\hline \multirow[t]{5}{*}{ Wet season } & Mavwet1 & 98.0 & 171.2 & 54.7 & 72.7 & 204.6 & 118.3 \\
\hline & Mavwet2 & 97.7 & 171.3 & 54.5 & 72.8 & 204.4 & 116.3 \\
\hline & Mavwet3 & 97.5 & 171.4 & 53.8 & 72.8 & 204.4 & 113.2 \\
\hline & Mavwet4 & 96.8 & 171.4 & 54.7 & 73.5 & 201.7 & 112.3 \\
\hline & Mavwet5 & 94.3 & 171.1 & 54.5 & 73.2 & 201.6 & 108.2 \\
\hline \multirow[t]{9}{*}{ Before birth } & Mavrain4_6 & 55.0 & & & & & \\
\hline & Mavain4_7 & 52.8 & & & & & \\
\hline & Mavrain5_9 & 54.6 & & & & & \\
\hline & Mavrain6_7 & 53.3 & & & & & \\
\hline & Mavrain6_8 & 53.7 & & & & & \\
\hline & Mavrain6_9 & 55.5 & & & & & \\
\hline & Mavrain7_8 & 55.0 & & & & & \\
\hline & Mavrain7_9 & 56.2 & & & & & \\
\hline & Mavrain8_9 & 56.0 & & & & & \\
\hline
\end{tabular}

${ }^{\dagger}$ The suffixes in rainfall component names denote the period over which the rainfall component was averaged. For example, Mavrain6 means the 6-month running mean of monthly rainfall, Mavrain4-6 means the average of monthly rainfall 4 to 6 months before the current month, etc.

\section{REFERENCES}

Albon, SD, Coulson, TN, Brown, D, Guinness, FE, Pemberton, JM \& Clutton-Brock, TH (2000) Temporal changes in key factors and key age groups influencing the population dynamics of female red deer. Journal of Animal Ecology, 69, 1099-110.

Bonenfant, C, Gaillard, J-M, Coulson T, Festa-Bianchet, M, Loison A, Garel, M, Loe LE, Blanchard, P, Pettorelli, N, Owen-Smith, N, Du Toit, J \& Duncan, P (2009) Empirical evidence of densitydependence in populations of large herbivores. Advances in Ecology Research, 41, 313-57.

Bourgarel, M, Fritz H, Gaillard, JM, De Garine-Wichatitsky, M \& Maudet, F (2002) Effects of annual rainfall and habitat types on the body mass of impala (Aepyceros melampus) in Zambezi Valley, Zimbabwe. African Journal of Ecology, 40, 186-93.

Boutton, TW, Tieszen, LL \& Imbamba, SK (1988a) Biomass dynamics of grassland vegetation in Kenya. African Journal of Ecology 26, 89101.

Boutton, TW, Tieszen, LL \& Imbamba, SK (1988b) Seasonal changes in the nutrient of East African grassland vegetation. African Journal of Ecology, 26, 103-15.

Burnham, KP \& Anderson, DR (2002) Model Selection and multi-model Inference: A Practical Information-Theoretic Approach. $2^{\text {nd }}$ ed. Springer Verlag, New York. 
Coe, MJ, Cumming, DH \& Phillipson, J (1976) Biomass and production of large African herbivores in relation to rainfall and primary production. Oecologia, 22, 341-54

Cronje, HP, Relly, BK \& Macfadyen, ID (2002) Natural mortality among common ungulate species in Letaba Ranch, Limpopo Province, South Africa. Koedoe, 45, 79-86.

Deshmukh, IK (1984) A common relationship between precipitation and grassland peak biomass for East and southern Africa. African Journal of Ecology, 22, 181-6.

Dunham, KM, Robertson, EF \& Grant, CC (2004) Rainfall and the decline of a rare antelope, the tsessebe (Damaliscus lunatus lunatus), in Kruger National Park, South Africa. Biological Conservation, 117, 83-94.

East R (1984) Rainfall, soil nutrient status and biomass of large African savanna mammals. African Journal of Ecology, 22, 245-70.

Ezenwa, OV (2004) Parasite infection rates of impala (Aepyceros melampus) in fenced game reserve in relation to reserve characteristics. Biological Conservation, 118, 397-401.

Fairall N (1983) Production parameters of the impala, Aepyceros melampus. South African Journal of Animal Science 13, 176-9.

Fairall, N \& Klein, DR (1984) Protein intake and water turnover: a comparison of two equivalently sized African antelope the blesbok Damaliscus dorcas and impala Aepyceros melampus. Canadian Journal of Animal Science, 64, 212-4

Festa-Bianchet, M \& Côte, SD (2008) Mountain goats: ecology, behavior, and conservation of an alpine ungulate. Island Press, Washington.

Fritz H \& Duncan P (1994) On the carrying capacity for large ungulates of African savanna ecosystems. Proceedings of the Royal Society, B, 256, 77-82.

Fritz H, Duncan, P, Gordon, IJ, Illius \& AW (2002) Megaherbivores influence trophic guilds structure in African ungulate communities. Oecologia, 131, 620-5.

Gaidet, N \& Gaillard J-M (2008) Density-dependent body condition and recruitment in a tropical ungulate. Canadian Journal of Zoology, $86,24-32$.

Gaillard, J-M, Festa-Bianchet, M \& Yoccoz, NG (1998) Population dynamics of large herbivores: variable recruitment with constant adult survival. Trends in Ecology and Evolution, 13, 58-63.

Gaillard, J-M, Festa-Bianchet, M, Yoccoz, NG, Loison, A \& Toigo C (2000) Temporal variation in fitness components and dynamics of large herbivores. Annual Review of Ecology and Systematics, 31, 367-93.

Gallivan, GJ, Barker, IK, Alves, RMR, Culverwell, J \& Girdwood, R (1989) Observations of the lungworm, Pneumostrongylus calcaratus, in impala (Aepyceros mealmpus) from Swaziland. Journal of Wildlife Diseases, 25, 76-82.

Georgiadis, N, Hack, M \& Turpin, K (2003) The influence of rainfall on zebra population dynamics: implications for management. Journal of Applied Ecology, 40, 125-36.

Georgiadis, N \& McNaughton, SJ (1990) Elemental and fiber contents of savanna grasses: variation with grazing, soil type, season and species. Journal of Applied Ecology, 27, 623-34.

Georgiadis, N, Olwero, JGN, Ojwang, G \& Romanach, SS (2007) Savanna herbivore dynamics in a livestock-dominated landscape. I. Dependence on land use, rainfall, density, and time. Biological Conservation, 137, 461-72.

Hopcraft, JGC, Olff, H \& Sinclair, ARE (2010) Herbivores, resources and risks: alternating regulation along primary environmental gradients in savannas. Trends in Ecology and Evolution, 25, 119-28.

Leuthold, BM \& Leuthold, W (1978) Daytime activity patterns of gerenuk and giraffe in Tsavo National Park, Kenya. African Journal of Ecology, 16, 231-43.

Lewis, JG (1977) Game domestication for animal production in Kenya: activity patterns of eland, oryx, buffalo and zebu cattle. Journal of Agricultural Science, 89, 551-63.

Maloiy, GMO \& Hopcraft, D (1971) Thermoregulation and water relations of two east African antelopes: the hartebeest and impala. Comparative Biochemistry and Physiology, 38, 525-34

McNaughton, SJ (1985) Ecology of a grazing ecosystem: The Serengeti. Ecological Monographs, 55, 259-94.

Mduma, SAR, Sinclair, ARE \& Hilborn, R (1999) Food regulates the Serengeti wildebeest: a 40-year record. Journal of Animal Ecology, $68,1101-22$

Metzger, KL, Sinclair, ARE, Hilborn, R, Hopcraft, JGC \& Mduma, SAR (2010) Evaluating the protection of wildlife in Sanctuarys: the case of African buffalo in Serengeti. Biodiverity Conservation, 19, 3431-3444

Moe SR, Rutina LP \& du Toit JT (2007) Trade-off between resource seasonality and predation risk explains reproductive chronology in impala. Journal of Zoology 273, 237-43.

Moulton, JE \& Sachs R (1970) Verminous pneoumonia in East African antelopes. Journal of Compative Pathology, 80, 169-73.

Nalubamba, KS, Mudenda, NB \& Malamo MR (2011) A seasonal survey of gastrointestinal parasites in captive wild impala antelope on a game facility south of Lusaka, Zambia. Journal of Helminthology. doi:10.1017/S0022149X11000617.

Ocaido, M, Siefert, L \& Baranga, J (1999) Seasonal changes of impala (Aepyceros melampus, Lichtenstein, 1812) faecal helminth egg counts through a one-year period. African Journal of Ecology, 37, 327-33

Oftedal, OT (1985) Pregnancy and lactation. In: Hudson, RJ \& White RG (Eds.) Bioenergetics of wild herbivores, Florida, CRC Press 21538.

Ogutu, JO \& Owen-Smith, N (2003) ENSO, rainfall and temperature influences on extreme population declines among African savanna ungulates. Ecology Letters, 6, 412-9.

Ogutu JO \& Owen-Smith N (2005) Oscillations in large mammal populations: are they related to predation or rainfall?. African Journal of Ecology 43, 332-9.

Ogutu, JO, Piepho, H-P, Dublin, HT, Bhola, N \& Reid, RS (2007) ENSO, rainfall and temperature fluctuations in the Mara-Serengeti ecosystem. African Journal of Ecology, 46, 132-43.

Ogutu JO, Piepho H.-P, Dublin, HT, Bhola N \& Reid, RS (2008) Rainfall influences on ungulate population abundance in the Mara-Serengeti ecosystem. Journal of Animal Ecology, 77, 814-29.

Ogutu, JO, Piepho, H-P, Dublin, HT, Bhola, N \& Reid, RS (2010) Rainfall extremes explain interannual shifts in timing and synchrony of breeding in topi and warthog. Population Ecology, 52, 89-92.

Ogutu, JO, Piepho, H-P, Dublin, HT, Bhola, N \& Reid, RS (2011). Dynamics of births and juvenile recruitment in Mara-Serengeti ungulates in relation to climatic and land use changes. Population Ecology, 53, 195-213.

Owen-Smith, N (1990) Demography of a large herbivore, the greater kudu Tragelaphusstrepsiceros, in relation to rainfall. Journal of Animal Ecology, 59, 893-913.

Owen-Smith, N (1993) Comparative mortality rates of male and female kudus: the costs of sexual size dimorphism. Journal of Animal Ecology, 62, 428-40.

Owen-Smith, N (1998) How high ambient temperature affects the daily activity and foraging time of a subtropical ungulate, the greater kudu (Tragelaphus strepiceros). Journal of Zoology, 246, 183-92.

Owen-Smith, N \& Ogutu, JO (2003) Rainfall influences on ungulate population dynamics. In: du Toi, J, Rogers, K \& Biggs, HC (Eds). The Kruger Experience: Ecology and Management of Savanna Heterogeneity, Washington, Island Press 310-3331.

Owen-Smith, N \& Mason, DR (2005) Comparative changes in adult vs. juvenile survival affecting population trends in African ungulates. Journal of Animal Ecology, 74, 762-73.

Owen-Smith, N \&Mills, MGL (2006) Manifold interactive influences on the population dynamics of a multispecies ungulate assemblage. Ecological Monographs, 76, 73-92.

Owen-Smith, N \& Mills, GL (2008) Shifting prey selection generates contrasting herbivore dynamics within a large-mammal predatorprey web. Ecology, 89, 1120-33.

Prins, HHT \& Weyerhaeuser, FJ (1987) Epidemics in populations of wild ruminants: anthrax and impala, rinderpest and buffalo in Lake Manyara National Park, Tanzania. Oikos, 49, 28-38.

Prins, HHT (1988) Plant phenology patterns in Lake Manyara National Park, Tanzania. Journal of Biogeography, 15, 465-80.

Sadleir, RMFS (1969) The Ecology of Reproduction in Wild and Domestic Animals. Methuen \& Co, London.

Sankaran, M, Hanan, NP, Scholes, RJ, Ratnam, J, Augustine, DJ, Cade, BS, Gignoux, J, Higgins, SI, Le Roux, X, Ludwig, F, Ardo, J, Banyikwa, F, Bronn, A, Bucini, G, Caylor, KK, Coughenour, MB, Diouf, A, Ekaya W, Feral1, CJ, February, EC, Frost PGH, Hiernaux, P, Hrabar, H, Metzger, KL, Prins, HHT, Ringrose, S, Sea, W, Tews, J, Worden, J \& Zambatis, N (2005) Determinants of woody cover in African savannas. Nature, 438, 846-9.

SAS, Institute (2011) SAS System for Windows, Version 9.3. SAS Institute, Carey, NC. 
Scholes, RJ \& Archer, SR (1997) Tree-grass interactions in savannas. Annual Review of Ecology and Systematics, 28, 517-44.

Sinclair, ARE (1975) The resource limitation of trophic levels in tropical grassland ecosystems. Journal of Animal Ecology, 44, 497-521.

Sinclair, ARE (1977) The African Buffalo. University of Chicago Press, Chicago.

Sinclair, ARE, Mduma, SAR \& Arcese, P (2000) What determines phenology and synchrony of ungulate breeding in Serengeti? Ecology, 81, 2100-11.

Sinclair, ARE, Mduma, SAR \& Brashares, JS (2003) Patterns of predation in a diverse predator-prey system. Nature, 425, 288-90.
Talbot, LM \& Talbot, MH (1963) The wildebeest in Western Maasialand, East Africa. Wildlife Monographs No. 12. The Wildlife Society, Washington, DC.

Toigo, C \& Gaillard, J-M (2003) Causes of sex-biased adult survival in ungulates: sexual size dimorphism, mating tactic or environmental harshness? Oikos, 101, 376-84.

Tolsma, DJ, Ernst, WHO, Verweij, RA \& Vooijs, R (1987) Seasonal variation of nutrient concentrations in a semi-arid savanna ecosystem in Botswana. Journal of Ecology, 75, 755-70.

Wafula, MM, Patrick, A \& Charles, T (2007) Managing the 2004/05 anthrax outbreak in Queen Elizabeth and Lake Mburo National Parks, Uganda. African Journal of Ecology, 46, 24-31.

(C) Ogutu et al.; Licensee Bentham Open.

This is an open access article licensed under the terms of the Creative Commons Attribution Non-Commercial License (http://creativecommons.org/ licenses/by-nc/3.0/), which permits unrestricted, non-commercial use, distribution and reproduction in any medium, provided the work is properly cited. 